\title{
Relationship of online Gaming addiction and study skills and habits of College Students
}

\author{
Bren C. Bondoc, MSIT
}

Instructor, College of Information and Communications Technology, Nueva Ecija University of Science and Technology

\begin{abstract}
Online gaming is one of the major trends today and is one of the most common source of entertainment for people specially students. However, it can be addictive and may have negative effect to students. This study described the college students' experiences in online gaming addiction. Also, it described the domains of study skills and habits of college students in terms of attitude, time management, goal setting, class preparation, and exam preparation. Further, it determined the relationships of college students' sex and year level with their online gaming experiences and the domains of study skills and habits. This study used the descriptive method. The researcher circulated a survey questionnaire with Likert-scale responses to a total of 115 college students consisting of 40 male students and 75 female students which year levels are 30 first year, 34 second year, 22 third year and 29 fourth year students. Based on the results of the study, the researcher concluded that college students' experiences in online gaming are as follows: they are not comfortable limiting their game time, they are bored when they do not play online games, they forgot to eat and they have stolen for gaming. However, college students did not necessarily neglect their responsibilities in school. In term of study skill and habits, the researcher concluded that college students have positive attitude to learn new things from school. They can start studying and they can keep it going. They do review practice problems to prepare for their class. Likewise, college students can adjust their study methods in terms of exam preparation. However, it is also concluded that they have on average goal setting plan though they are setting high standards for themselves in school. Furthermore, their sex and year level have nothing to do with their online gaming experiences and their study skills and habits. Same with their online gaming experiences are not associated with their study skills and habits. Since online gaming can be addicting, the researcher recommends that a school intervention should be done for the college students from where their experiences on it are quite alarming. Further study can be conducted focusing on the compulsive and obsessive behaviors of college students in relation to online gaming. Though positive results are present in terms of the study skills and habits of students, it is still recommended to have continuous monitoring not only of their skills and habits but on their academic performance in terms of academic grades, problems and deficiencies.
\end{abstract}

Keywords-Online Gaming, Online Gaming Addiction, Addiction, Study Habits, Study Skills

\section{INTRODUCTION}

Online gaming is one of the major trends today and is one of the most common source of entertainment for people specially students. However, it can be addictive and may have negative effect to students. With the increasing diversity of college students, the factors impacting academic performance are becoming even more important (Santos \&Celis, 2020).

A sort of troubling online gaming activity that bears similarities to the nature of the term and the addiction problem in such a way that it can be beneficially lend itself and compared with it (Hellman et al., 2013).In severe situations, prolonged video game play may have potentially adverse effects on people that tend to display compulsive and/or addictive habits close to those of other more conventional addictions (Griffiths et al., 2012).

Further, online players are mindful of their addictions to video gaming and are usually aware of the impact of their addictions on certain facets of their life, but their selfawareness is not equal to their addictions control (Lee et al., 2007).

ISSN: $2456-7620$ 
Thus, considerable interest has been focusing on the possibility of learning using online gaming and specific words have been coined to characterize this new educational resource, such as 'technology' and 'educational games' (Paraskeva et al., 2010)

\section{CONCEPTUAL FRAMEWORK}

Online gaming is more common among youth than among adults, and online gambling addiction is more likely among males than females(Ko et al., 2005).It's obvious that online players prefer to devote a lot of hours devoted to their game and find the social elements of the in-game environment of fun and rewarding than what happens in the real world $(\mathrm{Ng}$ \&Wiemer-Hastings, 2005).

Students defend their gaming and say it brought them a rich life with many meaningful experiences deserving of the possibility of addiction and displacement (Mozelius et al., 2016). Thus, parents and educators should be mindful of this and pay adequate attention to the psychological state of young online players (Liu \& Peng, 2009).

\section{OBJECTIVES OF THE STUDY}

This study described the college students' experiences in online gaming addiction. Also, it described the domains of study skills and habits of college students in terms of attitude, time management, goal setting, class preparation, and exam preparation. Further, it determined the relationships of college students' sex and year level with their online gaming experiences and the domains of study skills and habits.

\section{METHODOLOGY}

This study used the descriptive method. Descriptive approach is intended to collect knowledge about presenting current situations and to explain the complexity of the situation as it appears at the time of the analysis, and to investigate the causes of particular phenomena (Camic et al., 2003). The researcher circulated a survey questionnaire with likert-scale responses (Vagias, 2006) to a total of 115 college students consisting of 40 male students and 75 female students which year levels are 30 first year, 34 second year, 22 third year and 29 fourth year students.

\section{RESULTS AND DISCUSSIONS}

Table 1. College Students' Experiences in Online Gaming Addiction

\begin{tabular}{|l|l|l|}
\hline & Mean & Verbal Interpretation \\
\hline I lose hours of sleeping in online gaming. & 3.33 & Moderately True of Me \\
\hline I got angry when someone interrupts me from gaming. & 3.45 & Moderately True of Me \\
\hline I forgot to eat while gaming. & 3.64 & Moderately True of Me \\
\hline I used to enjoy online gaming other than recreational activities. & 3.34 & Somewhat True of Me \\
\hline I have less contact with my family members. & 3.51 & Moderately True of Me \\
\hline I have stolen anything for gaming. & 3.64 & Moderately True of Me \\
\hline I have suffered from any physical pains from intense gaming. & 3.36 & Somewhat True of Me \\
\hline I feel anxious when I skipped from my online games schedule. & 3.48 & Moderately True of Me \\
\hline I swore to stop online gaming but later returned to it. & 3.20 & Somewhat True of Me \\
\hline I fear a life without gaming. & 2.98 & Somewhat True of Me \\
\hline I only spend time with people who love online games. & 3.12 & Somewhat True of Me \\
\hline I neglect my responsibilities in school. & 1.81 & Slightly True of Me \\
\hline I hide to my family about my online gaming. & 3.16 & Somewhat True of Me \\
\hline I have tried limiting my game time but not find myself comfortable with it. & 3.81 & Moderately True of Me \\
\hline I find myself bored when I do not play online games. & 3.71 & Moderately True of Me \\
\hline Average Weighted Mean & 3.30 & Somewhat True of Me \\
\hline
\end{tabular}




$$
\begin{aligned}
& \text { Legend } \\
& 4.20-5.00 \\
& 3.40-4.19 \\
& 2.60-3.39
\end{aligned}
$$

Verbal Interpretation

$$
\text { Very True of Me }
$$

Moderately True of Me

Somewhat True of Me
$1.80-2.59$
Slightly True of Me
$1.00-1.79$
Not All true of Me

Table 1 shows the experiences of college students in online gaming addiction. Based on the result, college students scored an average weighted mean of 3.30 which means that the listed experiences were somewhat true of them. Items 14, 15, 3, and 6 got highest means accordingly. College students have tried limiting their game time but not find themselves comfortable with it $(X=3.81)$. They find themselves bored when they do not play online games $(X=$
3.71). likewise, they forgot to eat while gaming $(X=3.64)$ and they have stolen anything for gaming $(X=3.64)$. All of these experiences were moderately true of the college students. On the other hand, Item 12 got the lowest mean of

\begin{tabular}{|c|c|c|}
\hline & Mean & Verbal Interpretation \\
\hline \multicolumn{3}{|l|}{ Attitude } \\
\hline I love attending to my class. & 3.52 & Moderately True of Me \\
\hline I like learning new things in school. & 3.04 & Somewhat True of Me \\
\hline I know I can survive schooling even the subjects are hard. & 3.90 & Moderately True of Me \\
\hline I think I will get passing marks. & 3.46 & Moderately True of Me \\
\hline Average Weighted Mean & 3.68 & Moderately True of Me \\
\hline \multicolumn{3}{|l|}{ Time Management } \\
\hline I find it easy to stick to a study schedule. & 3.03 & Somewhat True of Me \\
\hline I spend more time on difficult subjects. & 3.67 & Moderately True of Me \\
\hline I have enough time to study. & 3.65 & Moderately True of Me \\
\hline I can start studying and keep it going. & 3.72 & Moderately True of Me \\
\hline Average Weighted Mean & 3.51 & Moderately True of Me \\
\hline \multicolumn{3}{|l|}{ Goal Setting } \\
\hline I set high standards for myself in school. & 3.46 & Moderately True of Me \\
\hline I am satisfied with my grades & 3.02 & Somewhat True of Me \\
\hline I persist when I find it challenging to concentrate studying. & 2.91 & Somewhat True of Me \\
\hline I work for my future plans. & 3.00 & Somewhat True of Me \\
\hline Average Weighted Mean & 3.10 & Somewhat True of Me \\
\hline \multicolumn{3}{|l|}{ Class Preparation } \\
\hline I read notes before class. & 3.53 & Moderately True of Me \\
\hline I do review practice problems. & 3.65 & Moderately True of Me \\
\hline I translate what I'm studying into my own words. & 3.54 & Moderately True of Me \\
\hline I make up and answer questions to test myself. & 3.40 & Moderately True of Me \\
\hline
\end{tabular}
1.81 with a verbal interpretation of 'slightly true of me'. This states that college students slightly neglect their responsibilities in school.

Table 2. Study Skills and Habits of College Students 
International Journal of English, Literature and Social Sciences, 5(2)

Available online: https://ijels.com/

\begin{tabular}{|l|l|l|}
\hline Average Weighted Mean & 3.38 & Moderately True of Me \\
\hline Exam Preparation & & \\
\hline I know what to study for an exam. & 3.53 & Moderately True of Me \\
\hline I adjust my study methods for different subjects. & 3.70 & Moderately True of Me \\
\hline I feel confident in my study methods. & 3.08 & Somewhat True of Me \\
\hline I take enough time to study difficult subjects. & 3.44 & Moderately True of Me \\
\hline Average Weighted Mean & 3.44 & Moderately True of Me \\
\hline
\end{tabular}

Legend

$$
\begin{aligned}
& 4.20-5.00 \\
& 3.40-4.19 \\
& 2.60-3.39
\end{aligned}
$$

Verbal Interpretation

Very True of Me

Moderately True of Me

Somewhat True of Me
$1.80-2.59$
$1.00-1.79$
Slightly True of Me
Not All true of Me

Table 2 shows the study skills and habits of college students in terms of attitude, time management, goal setting, class and exam preparations. In terms of attitude, college students scored an average weighted mean of 3.68 which means that the experiences under this domain were moderately true of them. College students know they can survive schooling even thesubjects are hard $(X=3.90)$ and this is moderately true of them. While, they like learning new things in $\operatorname{school}(X=3.04)$ is somewhat true of them. In time management, college students scored 3.51 on this domain which has a verbal interpretation of 'moderately true of me'. They moderately experienced that they can start studying and keep it going $(X=3.72)$ but they somewhat experienced to find it easy to stick to a study schedule $(X=3.03)$. In goal setting, college students got an average weighted mean of
3.10 stating that these experiences are somewhat true of the college students. They somewhat experience persist when the find it challenging to concentrate studying $(X=2.91)$ and they moderately experienced setting high standards for themselves in school $(X=3.46)$. In terms of class preparation, this domain got an average weighted mean of 3.38 and with a verbal interpretation of 'moderately true of me'. College students do review practice problems $(X=$ $3.65)$ and they make up and answer questions to test themselves $(X=3.40)$. Last, exam preparationgot an average weighted mean of 3.44. This shows that college students moderately experienced adjusting their study methods for different $\operatorname{subjects}(X=3.70)$ and they somewhat feel confident in their study methods $(X=3.08)$.

\begin{tabular}{|c|c|c|c|c|c|c|c|c|}
\hline & 1 & 2 & 3 & 4 & 5 & 6 & 7 & 8 \\
\hline Sex & - & -.026 & .067 & -.018 & .022 & .071 & -.065 & .086 \\
\hline Year Level & & - & .054 & -.056 & -.054 & -.049 & .033 & -.074 \\
\hline Online Gaming Experiences & & & - & .058 & -.083 & -.109 & -.042 & -.048 \\
\hline Attitude & & & & - & -.144 & .169 & -.044 & .154 \\
\hline Time Management & & & & & - & -.140 & .065 & .015 \\
\hline Goal Setting & & & & & & - & -.062 & .114 \\
\hline Class Preparation & & & & & & & - & -.109 \\
\hline Exam Preparation & & & & & & & & - \\
\hline
\end{tabular}

Table 3. Relationships of College Students' Sex and Year Level with their Online Gaming Experiences and the Domains of Study Skills and Habits 
Table 3 presents the relationships ofsex and year level of the college students with their online gaming experiences and their study skills and habits (attitude, time management, goal setting, class preparation and exam preparation). Using Pearson $r$ correlation, it was found out that sex and year level of college students do not have significant relationships with their online gaming experiences and their study skills and habits. Furthermore, there were also no significant relationships when tested between all variables.

\section{CONCLUSIONS AND RECOMMENDATIONS}

Based on the results of the study, the researcher concluded that college students' experiences in online gaming are as follows: they are not comfortable limiting their game time, they are bored when they do not play online games, they forgot to eat and they have stolen for gaming. However, college students did not necessarily neglect their responsibilities in school. In term of study skill and habits, the researcher concluded that college students have positive attitude to learn new things from school. They can start studying and they can keep it going. They do review practice problems to prepare for their class. Likewise, college students can adjust their study methods in terms of exam preparation. However, it is also concluded that they have on average goal setting plan though they are setting high standards for themselves in school. Furthermore, their sex and year level have nothing to do with their online gaming experiences and their study skills and habits. Same with their online gaming experiences are not associated with their study skills and habits.

Since online gaming can be addicting, the researcher recommends that a school intervention should be done for the college students from where their experiences on it are quite alarming. Further study can be conducted focusing on the compulsive and obsessive behaviors of college students in relation to online gaming. Though positive results are present in terms of the study skills and habits of students, it is still recommended to have continuous monitoring not only of their skills and habits but on their academic performance in terms of academic grades, problems and deficiencies.

\section{REFERENCES}

[1] Camic, P. M., Rhodes, J. E., \& Yardley, L. E. (2003). Qualitative research in psychology: Expanding perspectives in methodology and design. American Psychological Association.
[2] D Griffiths, M., J Kuss, D., \& L King, D. (2012). Video game addiction: Past, present and future. Current Psychiatry Reviews, 8(4), 308-318.

[3] Hellman, M., Schoenmakers, T. M., Nordstrom, B. R., \& van Holst, R. J. (2013). Is there such a thing as online video game addiction? A cross-disciplinary review. Addiction Research \& Theory, 21(2), 102-112.

[4] Ko, C. H., Yen, J. Y., Chen, C. C., Chen, S. H., \& Yen, C. F. (2005). Gender differences and related factors affecting online gaming addiction among Taiwanese adolescents. The Journal of nervous and mental disease, 193(4), 273-277.

[5] Lee, I., Yu, C. Y., \& Lin, H. (2007). Leaving a Never-Ending Game: Quitting MMORPGs and Online Gaming Addiction. In DiGRA Conference.

[6] Liu, M., \& Peng, W. (2009). Cognitive and psychological predictors of the negative outcomes associated with playing MMOGs (massively multiplayer online games). Computers in Human Behavior, 25(6), 1306-1311.

[7] Mozelius, P., Westin, T., Wiklund, M., \&Norberg, L. (2016, October). Gaming habits, study habits and compulsive gaming among digital gaming natives. In The 10th European Conference on Games Based Learning (ECGBL), Paisley, United Kingdom, 6th to 7th October 2016. Academic Conferences Publishing.

[8] Ng, B. D., \&Wiemer-Hastings, P. (2005). Addiction to the internet and online gaming. Cyberpsychology\& behavior, 8(2), $110-113$

[9] Paraskeva, F., Mysirlaki, S., \&Papagianni, A. (2010). Multiplayer online games as educational tools: Facing new challenges in learning. Computers \& Education, 54(2), 498505 .

[10] Santos, K. E. S., \&Celis, A. J. D. (2020). Institutional Factors affecting Academic Performance of Marketing Students in Nueva Ecija. International Journal of English Literature and Social Sciences (IJELS), 5(1).

[11] Vagias, W. M. (2006). Likert-type scale response anchors. clemson international institute for tourism. \& Research Development, Department of Parks, Recreation and Tourism Management, Clemson University. 